\title{
Analysis of The Implementation of Non-cash Food Assistance (BPNT) Program for Reducing Poverty in Sub-district Panjang, Bandar Lampung 2018
}

\author{
Vishnu Juwono ${ }^{1}$, Nabila Kharimah Vedy ${ }^{2}$ \\ \{vjuwono@ui.ac.id'1 ,nabilakv@gmail.com\} \\ Faculty of Administrative Science, Universitas Indonesia, Depok, Indonesia ${ }^{1}$, Faculty of \\ Administrative Science, Universitas Indonesia, Depok, Indonesia ${ }^{2}$
}

\begin{abstract}
One of the Indonesian government's efforts to reduce poverty is through the Non-Cash Food Assistance (BPNT) program. BPNT is a transformation of Rice for Poor (Rastra) which provides food assistance through an electronic account mechanism. However, the poverty in some provinces has increased. The purpose of this study is to analyze the implementation of BPNT in Sub-district Panjang and find out the factors that influence the implementation of BPNT. This research is conducted with a post-positive approach, while data collection technique using qualitative methods through in-depth interview and literature. This research uses the theory of Khandaker \& Khan's rational model, subsidy, public policy, and the implementation of public policy. The result shows that the implementation of BPNT in Sub-district Panjang is still not as expected. The factors that influence the implementation include the lack of understanding of the actor's duties, incomplete regulations, and lack of monitoring at the sub-district level.
\end{abstract}

Keywords: Non-Cash Food Assistance, Public Policy, Implementation Policy, Subsidy.

\section{Introduction}

Poverty still becomes a problem and the focus of the global development agenda [1]. In 2015, countries agreed on the Sustainable Development Goals (SDGs) as an effort to alleviate the problem of poverty [2]. Indonesia is one of the countries facing the problem of poverty. According to Bank Indonesia [3], the number of poor people in Indonesia is still large, even though Indonesia has good economic growth. In March 2018, the number of poor people in Indonesia reached 25,95 million people [4].

The poverty rate in Indonesia is strongly influenced by food commodities. The decline in the poverty rate in Indonesia is related to low and stable food inflation [5]. In fact, rice is the food commodity which has a large portion of expenditure on poor households in urban areas $(20.95 \%)$ an rural areas $(26.97 \%)$ [4]. In this case, the increase in food prices, especially rice, has an influence on increasing poverty rates [6]. Therefore, one of the Indonesian government's efforts to reduce poverty and fulfil the basic food needs of the Indonesian people is through a food assistance program.

The food assistance program in Indonesia began in 1998 when Indonesia experienced a monetary crisis. The government implemented "Special Market Operations (OPK)" to protect low income households [7]. OPK provided subsidized rice prices at Rp. 1,000/kg for $10 \mathrm{~kg}$ for low-income households every month [8]. In 2002, the OPK program transformed into a Rice 
for the Poor (Raskin) program which supplied subsidized rice prices at Rp. 1,600/kg for $15 \mathrm{~kg}$ [9]. In 2015, the Raskin program changed its name to prosperous rice program (Rastra) [10]. Meanwhile, the implementation of Rastra program was considered ineffective, based on the result of the research held in Bandung, Makassar, Jakarta Barat, Surabaya, and Bekasi in 2018 [11]. Hence, in 2017 the Indonesian Government converted the Rastra program into Non-Cash Food Assistance Program (BPNT) through "Presidential Regulation No. 63 of 2017 concerning Non-Cash Social Food Assistance".

BPNT program provides food assistance in the form of rice and eggs through an electronic account mechanism. Every month, Beneficiary Families (KPM) get a balance on the Prosperous Family Card (KKS) of Rp. 110,000. The balance can be exchanged for rice and eggs in Ewarong. The aims of the BPNT program are to reduce the KPM burden in food expenditure and provide more balanced nutrition [12].

BPNT has an important role to decrease the poverty rate for regions that have serious poverty problems. Lampung Province is one of seven provinces that experienced an increase in the poverty rate. The poverty rate in Lampung Province reached $13.14 \%$ higher than the national poverty rate of $9.82 \%$ [13]. The number of poor people in Lampung Province reached 1,097.05 thousand people [13]. Rice commodities have a major influence on the increase in the poverty rate. In fact, Lampung Province is ranked 7 th in Indonesia as a rice self-sufficiency province [14].

The BPNT program in Lampung Province in 2018 was only held in two cities namely Bandar Lampung City and Metro City because it was a new program. Bandar Lampung City received 49,711 quotas of KPM, while Metro City received 6,078 quotas of KPM [15]. BPNT in Bandar Lampung City is distributed to 20 sub-districts. The sub-district in Bandar Lampung City which has the largest number of KPM is Panjang Sub-district (4,446 KPM) [15]. In addition, Panjang Sub-district has the largest population in Bandar Lampung City, which is 77,198 people spread across 8 urban villages [13]. Therefore, the effective implementation of the BPNT program is needed to overcome poverty problems in Panjang Sub-District. Based on the background of the problem above, this research is conducted to analyze the implementation of BPNT program in Panjang sub-district and find out the factors that influence that implementation of BPNT program.

\section{Theoretical Review}

This research uses theories such as subsidy, public policy, and the implementation of public policy. Subsidy is a form of government expenditure as the fulfilment of state social duties [16]. Two types of subsidies are In-Kind Transfer and Cash Transfer. In-Kind Transfer is a subsidy in the form of goods and programs [17]. Therefore, Cash Transfer is a subsidy in the form of funds such as the Conditional Cash Transfer (CCT). CCT is designed to provide salaries for households to invest in human capital through high discounts on education or health care rates [18].

Public policy is a guideline in carrying out actions, a broad framework of philosophies, and principles, visions, and decisions that are manifested in various programs, projects, and activities [19] [20]. Atmosudirdjo [20] and Khandaker and Khan [19] view public policy as a guideline in carrying out an activity. Basically, public policy is a dynamic thing that is influenced by certain conditions. Public policy is a very dynamic concept so that it can change in time and place [21]. This is in line with the opinion of Kraft and Furlong [22], public policy 
is strongly influenced by social and economic conditions, prevailing political values and public moods, Government structures, local and national cultural norms, and many other variables.

This study discusses the implementation of the BPNT program policy in Panjang Subdistrict. Implementation is one of the activities in the policy process [23]. Implementation becomes an important stage and must have clear objectives In this case, implementation has an important role as a determinant of the success or failure of policy [19]. The main theory used for this research to find out the factors that influence the success of policy implementation is "The Rational Policy Implementation Model" [19]. According to the theory [19], there are five factors that influence the success of policy implementation: 1. Clarity of policy goals, targets and objectives 2. Accurate and consistent planning 3. Clear and detailed task assignments 4 . Accurate standardization 5. Proper Monitoring Implementation Performance.

\section{Research Method}

This study uses a post-positivist approach. According to Creswell [24], a post-positivist approach must begin research by testing certain theories, after which collecting data that supports or does not support the theory, and makes further improvements before the recitation is carried out. On the other hand, the technique of collecting data in this study uses qualitative methods with in-depth interviews and literature. In-depth interviews are the process of obtaining information by conducting a question and answer session in person with the interviewee according to the interview [25]. Interviews are involved with several questions to informants related to topic of research, namely The Head of Assistance and Social Security of Social Service Bandar Lampung City, the Head of Panjang Sub-district, District Social Welfare Workers (TKSK), Community Social Workers (PSM), the Beneficiary Families (KPM), and Ewarong Owner. In addition, data collection techniques used in this study, related to Non-Cash Food Assistance (BPNT) such as policy products, data from local governments, books and journals, and BPNT guidelines. The location of this research is Panjang Sub-district, Bandar Lampung City. The study is conducted in selecting two villages specifically Way Lunik and Panjang Utara. This research is held during September-December 2018.

\section{Result and Discussion}

\section{1 The Implementation of Non-Cash Food Assistance (BPNT) Program in Sub-District Panjang \\ 4.1. 1 Preparation for Implementation of BPNT in Panjang Sub-District}

The preparation before BPNT distribution in Panjang begins with coordination between institution and E-warong preparation. The coordination starts with the notification from the Bandar Lampung City Social Service to Panjang Sub-district regarding the BPNT program. The Panjang Sub-district coordinates with the urban village officers and Pamong. Coordination is also carried out with the Bank Rakyat Indonesia (BRI) and Sub-District Social Welfare Workers (TKSK). Furthermore, TKSK informs BPNT program to Beneficiaries Family (KPM) in Panjang Sub-district. 
Table 1. Data of Beneficiary Families (KPM) and E-warong in Panjang Sub-District 2018 [26]

\begin{tabular}{ccccc}
\hline No. & Urban Village & Total KPM & \multicolumn{2}{c}{ Total E-warong } \\
\cline { 4 - 5 } & & & E-warong & BRILink \\
\hline 1. & Srengsem & 463 & 1 & - \\
2. & Panjang Utara & 584 & 1 & 1 \\
3. & Karang Maritim & 698 & 1 & - \\
4. & Panjang Selatan & 496 & - & - \\
5. & Pidada & 605 & - & 1 \\
6. & Way Lunik & 947 & 1 & 2 \\
7. & Ketapang & 457 & - & 1 \\
8. & Ketapang Kuala & 196 & 1 & - \\
& Total & $\mathbf{4 , 4 4 6}$ & $\mathbf{5}$ & $\mathbf{5}$ \\
\end{tabular}

E-warong preparation starts with the preparation of data about the number of KPM to decide the number of E-warong [27]. The number of KPM that receives BPNT in Panjang Sub-district after being validated is 4,446 KPM. While the number of E-warong available is $10 \mathrm{E}$-warong consisting of E-warong and BRILink. BRILink is a type of E-warong managed by Bank BRI. Based on the results of data analysis on the number of KPM compared to the availability of Ewarong numbers (in table 1), the number of E-warong in Panjang Sub-district is not in accordance with the regulation for every E-warong maximum serving 250 KPM $(1: 250)$ [27]. E-warong in Panjang Sub-district serves KPM in excess of the capacity. Furthermore, there is still a village which does not have E-warong such as Panjang Selatan.

\subsection{Mechanism of BPNT Distribution in Panjang Sub-District}

The BPNT distribution mechanism consists of four stages, namely socialization and education, registration, distribution, and purchase of goods/utilization [27]. Firstly, socialization and education have been carried out by the Social Service Office of Bandar Lampung City, TKSK, PSM, and neighbourhood (RT) to KPM. However, KPM still lacks understanding about the BPNT program such as the function of the Prosperous Family Card (KKS). Secondly, registration has some problems such as the long registration process that takes more than a year and the verification data that has been verified and submitted to the Government is not being processed. Consequently, the KPM that gets food assistance remains the same person. Thirdly, the distribution of BPNT is still not on a target nor on time. There is a gap between the number of KPM quota (4,650 KPM) and the actual KPM who received BPNT (4,446 KPM), and there are still poor people who don't receive assistance due to verification data not being process the practice of nepotism. The schedule of BPNT distribution is uncertain. This problem occurs due to zero balance and signal problems. Fourthly, the forms of food assistance which is received by KPM are not in accordance with the new regulation of BPNT 2018 namely, sugar, oil, eggs, and rice. In fact, there are some frauds in the utilization of BPNT in Panjang Sub-district such as KPM receives packed food assistance every month, detention of the KKS card in Urban Villages and Illegal levy that KPM pays some amount of money as an administration expense whereas this assistance is free of charge.

\subsection{Allocation of BPNT Resources in Panjang Sub-district}

The allocation of resources consists of facilities and human resources. Firstly, the facilities provided by the local government for the distribution of BPNT are E-warong and Edition. The Government ensures that E-warong has been filled with food assistance. In addition, the facilities prepared are "Edisi". This "edisi" is used to distribute BPNT by using electronic 
mechanisms. Secondly, panjang sub-district has merely one District Social Welfare Worker (TKSK) who is in charge of maintaining BPNT Distribution in eight urban villages. According to the interview with TKSK, there are no special skills qualifications for becoming TKSK. Nevertheless, TKSK in Panjang Sub-district continues to receive Stabilization Guidance" (BIMTA) to teach TKSK in overcoming problems.

\subsection{The Factors that Influence The Implementation of Non-Cash Food Assistance (BPNT) Program in Sub-District Panjang \\ 4.2. 1 The Clarity of BPNT Policy in Panjang Sub-district}

According to Anderson on Widodo [28], policy always has a goal or goal-oriented certain. Consequently, the clarity of policy goals is needed. The clarity of the BPNT program can be assessed based on the BPNT goals in "Minister of Social Affairs Regulation No. 11 of 2018 concerning Non-Cash Food Assistance" [27]. The regulation consists of four goals of BPNT which are and realistic to achieve.

\subsection{Clear and Detailed Tasks of BPNT Program Actors}

The main actor of the BPNT program in sub-district level is Social Welfare Worker (TKSK). Social Welfare Worker (TKSK). The clear and detailed tasks of TKSK can be seen from the understanding of TKSK about the tasks based on the regulation [27]. According to the interview with TKSK in Panjang, TKSK in Panjang only knows that the duties are limited in terms of monitoring and reporting problems. Though, there are other duties of TKSK which are to assist the poor households in attending education, socialization program, and accompany the poor household in the registration process, and to coordinate with the Social Service Office of Bandar Lampung City, Panjang Sub-district, and Urban villages. To conclude, TKSK has not fully understood the tasks that should be carried out.

\subsection{Accurate Standardization of the BPNT Program}

Accurate standardization can be seen from government regulations and BPNT guidelines. These rules are contained in "General Guidelines for the Implementation of Non-Cash Food Assistance 2018", "Republic of Indonesia Presidential Regulation Number 63 of 2017 regarding Non-Cash Distribution of Social Assistance", and "Republic of Indonesia Social Minister Regulation Number 11 of 2018 concerning Non-Cash Food Assistance (BPNT) Distribution" [29] [27] [30]. Based on the results of the analysis, the rules and guidelines of BPNT are quite accurate, containing enough rules for distributing BPNT. However, there is no clear regulation regarding the duties of the Regional Government at the Sub-district level. Because of that, the Panjang Sub-district official has a limited role like providing facilities and giving permission for BPNT distribution.

\subsection{Proper Monitoring of BPNT Distribution in Panjang Sub-district}

The supervision is carried out by Social Service of Bandar Lampung City and Welfare Social Worker (TKSK) through field visits, reporting, and coordination meetings. Therefore, fraud problems are still found even though the supervision is routinely performed by TKSK in Panjang and Social Service of Bandar Lampung City. It occurs due to lack of monitoring at the sub-district level and urban village officials are not involved in supervision.

\subsection{Accurate and Consistent BPNT Program Planning}

The accuracy and consistency of BPNT program planning can be rated based on the appropriateness of the National Medium-Term Development Plan (RPJMN) 2015-2019, Government Work Plan (RKP) 2018, and Ministry of Social Affairs Strategic Plan 2015-2019 [31] [32] [33]. In Presidential Regulation number 79 of 2017 concerning Government Work Plans (RKP) 2018 which refers to the RPJMN 2015-2019, BPNT is a part of the national priority program to reduce poverty namely "Guarantee and Social Assistance Priority Program". 
The Ministry of Social Affairs Strategic Plan 2015-2019 is an elaboration of "Presidential Regulation No. 2 of 2015 concerning RPJMN for 2015-2019 ". BPNT program becomes a priority program in "Draft Road Map for Comprehensive Implementation of Social Protection Activities". Furthermore, The Ministry of Social Affairs has a role in implementing the "Social Security and Assistance Program" in accordance with the RKP 2018. One of the activities of the "guarantee and social assistance program" is the distribution of BPNT with a target of 10 million KPM. Based on the results of the explanation, the planning of BPNT in the Ministry of Social Affairs is in accordance with the RPJMN 2015-2019 and RKP 2018.

\section{Conclusion}

The results of this study indicate that the implementation of the Non-Cash Food Assistance (BPNT) program in Panjang District is not as expected. This is related to the implementation of BPNT which is not in accordance with the provisions such as the number of E-warong, registration process, verification data, education and socialization, time of BPNT distribution, the target of the beneficiary, and form of assistance. In addition, there are some problems found such as zero balance account, signal problem, packaged assistance, detention of card, and illegal levy.

The implementation of the BPNT program in Panjang Sub-district is influenced by some factors, including (1) Social Welfare Workers' lack of understanding of the tasks and responsibilities that have been given; (2) There are no clear regulations that contain the duties and responsibilities of the sub-district; (3) Lack of supervision at the sub-district level because sub-districts and urban village officials are not involved in supervision.

Therefore, there are several suggestions to the government: (1) The Ministry of Social Affairs needs to collaborate with the Ministry of Home Affairs to involve the role of Sub-district and Urban village officials in terms of supervising the distribution of BPNT; (2) The Ministry of Social Affairs makes a policy that contains the duties and responsibilities of Regional Government such as Sub-Districts and Urban Village officials;

\section{Acknowledgements}

The authors would like to thank all related actors to this research especially The Head of Assistance and Social Security of Social Service Bandar Lampung City, The Head of Panjang Sub-district, TKSK, PSM, and KPM in Panjang Subdistrict.

\section{References}

[1] A. D. Putera, "Hidup Pas-pasan dan Memahami Kemiskinan dari Perspektif Lain [Mediocre Life and Understanding Poverty from Another Perspective]," Kompas, 26 October 2018. [Online]. Available: https://ekonomi.kompas.com/read/2018/10/26/101806626/hidup-pas-pasan-dan-memahamikemiskinan-dari-perspektif-lain. [Accessed 29 October 2018].

[2] United Nations, "Draft Outcome Document of the United Nations Summit for the Adoption of the Post2015 Development Agenda. A/69/L.85," 2015.

[3] Bank Indonesia, "Economic Report on Indonesia, No. XXVII," Bank Indonesia, 2015. 
[4] BPS (Badan Pusat Statistik: Statistics Indonesia, formerly Central Bureau of Statistics), "Profil Kemiskinan di Indonesia Bulan Maret 2018 [Poverty Profile in Indonesia in March 2018]," 2018.

[5] Bank Indonesia, "Economic Report 2017," 2017.

[6] H. Purnomo, "Kenaikan Harga Beras Dongkrak Angka Kemiskinan [The Increasing of Rice Price Escalate the Poverty Rate]," Liputan 6, 17 July 2018. [Online]. Available: https://www.cnbcindonesia.com/news/20180717141531-4-23967/harga-beras-meroket-angkakemiskinan-yang--harusnya--rendah. [Accessed 30 October 2018].

[7] A. Suryahadi and R. A. Izzati, "Cards for the Poor and Funds for Villages: Jokowi's Initiatives to Reduce Poverty and Inequality," SMERU Working Paper: Draft, 2018.

[8] S. R. Tabor and M. H. Sawit, "Social Protection Via Rice: The OPK Rice Subsidy Program in Indonesia," The Developing Economies, vol. XXXIX, no. 3, pp. 267-94, 2001.

[9] Social Ministry of the Republic Indonesia, "General Guidelines for Poor Rice 2014," 2014.

[10] D. Caroline, "Menteri Sosial Ubah Nama Raskin Jadi Rastra [Minister of Social Affairs Changes Name of Poor Rice to Prosperous Rice]," Liputan 6, 28 August 2015. [Online]. Available: https://regional.kompas.com/read/2015/08/28/13143611/Menteri.Sosial.Ubah.Nama.Raskin.Jadi.Rastra. [Accessed 7 November 2018].

[11] B. Rachman, A. Agustian and Wahyudi, "Efektivitas dan Perspektif Pelaksanaan Program Beras Sejahtera (Rastra) dan Bantuan Pangan Non Tunai (BPNT) [Effectiveness and Perspective of the Implementation of the Prosperous Rice Program (Rastra) and Non-Cash Food Aid (BPNT)]," Analisis Kebijakan Pertanian, vol. 16, no. 1, pp. 1-18, June 2018.

[12] The Coordinating Ministry for Human Development and Culture of the Republic of Indonesia, "Guidelines for Implementing Non-Cash Food Assistance (BPNT)," 2017.

[13] BPS Lampung Province (Badan Pusat Statistik: Statistics Indonesia, formerly Central Bureau of Statistics), "Angka Kemiskinan Lampung 2018 [Lampung Poverty Rate 2018]," 2018.

[14] D. Murdaningsih, "Kementan Klaim Lampung Swasembada Padi dan Jagung [Ministry of Agriculture Claims Lampung's Rice and Corn Self-Sufficiency]," republika, 22 November 2017. [Online]. Available: https://www.republika.co.id/berita/ekonomi/makro/17/11/22/ozstnn368-kementan-klaimLampung-swasembada-padi-dan-jagung. [Accessed 31 october 2018].

[15] Indonesian government, "Decree of the Minister of Social Affairs of the Republic of Indonesia No. 4 / HUK / 2018," 2018.

[16] I. Putong, Ekonomi Makro: Pengantar untuk Dasar-Dasar Ilmu Ekonomi Makro [Macroeconomics: Introduction to the Basics of Macroeconomics], vol. Vol. 1, 2015.

[17] J. Currie dan F. Gahvari, "Transfers In Cash and In-Kind: Theory Meets The Data," J. Econ. Lit., Am. Econ. Assoc, vol. 46, no. (2), p. 333-38, 2008.

[18] J. Manley, S. Gitter dan V. Slachevsky, "How Effective are Cash Transfers at Improving Nutritional Status?,"World Development, vol. 48, pp. 133-155, 2013.

[19] S. Khandaker dan A. Khan, "A Critical Insight into Policy Implementation and Implementation Performance," Public Policy And Administration, vol. 15, no. 4, pp. 538-548, 2016.

[20] P. Atmosudirdjo, Dasar-dasar Administrasi Negara [The basics of Public Administration], Jakarta: Ghalia Indonesia, 1990.

[21] A. Farazmand, Global Encyclopedia of Public Administration, Public Policy, and Governance, Springer International Publishing 1st ed, 2018.

[22] M. E. Kraft dan S. R. Furlong, Public Policy: Politics, Analysis, and Alternatives, United State of America: University of Wisconsin, 2015.

[23] X. Wu, M. Ramesh, M. Howlett dan S. A. Fritzen, The Public Policy Primer: Managing the Policy Process, New York: 2nd ed. Routledge, 2010. 
[24] J. W. Creswell, Research Design: Pendekatan Kualitatif, Kuantitatif, dan Mixed [Qualitative, Quantitative, and Mixed Approaches], Yogyakarta: Pustaka Pelajar, 2010.

[25] J. Noor, Metodologi Penelitian Skripsi, Tesis, Disertasi \& Karya Ilmiah [Research Methodology of Thesis, Dissertation \& Scientific Paper], Jakarta: Kencana Prenada Media Group, 2011.

[26] Lampung provincial social service, "Panjang Sub-district Urban Village's data," 2018.

[27] Indonesian Government, "Minister of Social Affairs Regulation No.11 of 2018 concerning Non-Cash Food Assistance (BPNT)," 2018.

[28] J. Widodo, Analisis Kebijakan Publik [Public Policy Analysis], Jakarta: Bayumedia, 2008.

[29] Indonesian Government, "Presidential Regulation Number 63 of 2017 regarding Non-Cash Distribution of Social Assistance," 2017.

[30] Social Ministry of the Republic Indonesia, "General Guidelines for the Implementation of Non-Cash Food Assistance 2018," 2018

[31] Indonesian Government, "The National Medium-Term Development Plan (RPJMN) 2015-2019," 2015.

[32] Indonesian Government, “Government Work Plan (RKP) 2018," 2018.

[33] Indonesian Government, "Ministry of Social Affairs Strategic Plan 2015-2019,” 2015. 